\title{
Lesson from Vernacular Tobacco Barn: A Passive Design Strategy for Energy-Independent Building
}

\author{
Andika Citraningrum $^{1 *}$, Daning Herawati ${ }^{2}$ \\ ${ }^{1,2}$ Department of Architecture, Faculty of Engineering, Universitas Brawijaya, Malang, Indonesia. \\ *Corresponding author. Email: andikacitra@ub.ac.id
}

\begin{abstract}
Gudang Atag is one of Indonesia's vernacular buildings, which is a characteristic of the Na-Oogst tobacco plantation as raw material for cigars. This tobacco barn can produce tobacco leaves with quality that conforms to the standard using the process of air curing. Air curing is the process of drying tobacco using only wind inside the building-without mechanical support, thus makes Gudang Atag classified as an energy-independent building. Building performance is supported by the envelope, building size, wind availability, and tobacco barn workers. From the studies conducted, several passive design strategies might be applied as adaptations from the concept of air curing in Gudang Atag.

Keywords: Gudang Atag, tobacco barn, passive design strategy, energy-independent
\end{abstract}

\section{INTRODUCTION}

The impact of climate change in the form of rising air temperatures has been felt by people in various parts of the world. The World Meteorological Organization (WMO) has confirmed 2015, 2016, 2017, and 2018 as the four warmest years on record compared to the pre-industrial baseline (1850-1900) [1]. The IPCC Special Report on Global Warming of $1.5^{\circ} \mathrm{C}$ (IPCC SR15) reported that the average global temperature for the past five years, 20142018 was $1.04 \pm 0.09^{\circ} \mathrm{C}$ above a pre-industrial baseline [2]. Conditions in Indonesia, as reported by the Climatology and Geophysics Meteorological Agency [3], showed 2016 to be the hottest year $\left(0.8^{\circ} \mathrm{C}\right.$ compared to the baseline period 1981-2010), followed by 2015 in the second rank $\left(+0.5^{\circ} \mathrm{C}\right) .2018$ itself ranks third $\left(+0.46^{\circ} \mathrm{C}\right)$.

These conditions cause an increased need for artificial cooling in buildings. The International Energy Agency (IEA) said in 2016, cooling accounted for $18.5 \%$ of total electricity use in buildings. Through simulation with the Baseline Scenario, which takes account of the likely effects of current policies and targets, global energy use for space cooling will triple by 2050 [4].

On the other hand, many examples of vernacular buildings in Indonesia have so far been successful in maintaining thermal comfort in buildings naturally and independently of energy. One of the exemplary buildings is vernacular tobacco barn. The building has existed since the 1850s, since the Dutch colonial era. This building, which is often called "Los/ Gudang Atag" as a place for drying tobacco, is a characteristic of regions that have tobacco plantation commodities that are used as raw material for cigars. Indonesia has several vernacular tobacco barns that still exist, including in Medan, Klaten, and Jember. At the beginning of its construction, its existence supported three plantation areas and tobacco factories in the Dutch era, namely Vereenigde Deli Maatschappij (VDM) in North
Sumatra, NV. Klatensche Cultuurmaatschappij (NV. KCM) in Klaten, Surakarta Residency and Landbouw Maatschappij Oud-Djember (LMOD) in Jember, Besuki Residency, East Java [5].

The building is a long booth with bamboo structure, the building envelope made of thatch leaves or sugar cane leaves, and soil as the flooring. This tobacco barn can produce tobacco leaves with quality that conforms to the standard using the process of air curing. Air curing is the process of drying tobacco using only wind inside the building-without mechanical support, thus makes Gudang Atag classified as an energy-independent building. Therefore, this study aims to investigate the way Gudang Atag works in drying tobacco and the concepts which can be adapted to contemporary architecture concepts.

\section{RESEARCH METHODS}

The location of the study was in PTPN X Dusun Curah Rejo, Sukamakmur Ajung Village, Jember Regency, Indonesia with coordinates $8^{\circ} 14^{\prime} 03.8^{\prime \prime S}$ and $113^{\circ} 38^{\prime} 30.9^{\prime \prime E}$. The object under study was one Gudang Atag building with a building area of $1,240 \mathrm{~m}^{2}$ and site area of $17,400 \mathrm{~m} 2$. The location of Gudang Atag is surrounded by rice fields in the north and east, and by residential areas in the west and south.

The tobacco barn site is also located close to the tobacco planting area with a distance of approximately $500 \mathrm{~m}-1$ $\mathrm{km}$, making it easy to distribute post-harvest tobacco from the harvest area to the tobacco barn area for drying.

The study was conducted by direct observation and measurement in the field. The purpose is to analyze the building condition, also to measure the air temperature, humidity, and wind speed inside and outside the building. The following stages of the survey were conducted: 


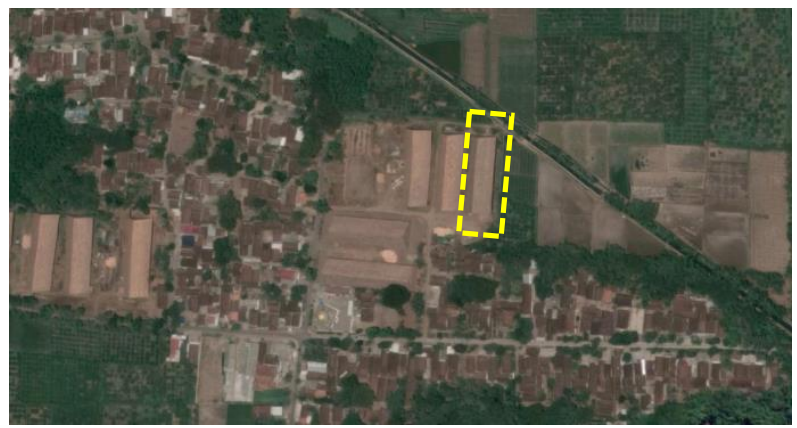

Figure 1 Location of Gudang Atag.

- First, the researchers prepare the research instruments: a camera to for visual documentation; a measuring meter to measure the size of the tobacco barn, including ventilation and distance between tobacco barn; a hot wire anemometer to measure wind speeds inside and outside the building; a thermometer hygrometer to measure temperature and humidity outside and inside the tobacco barn; and floor plans with 45 measurement points inside the building and 6 points outside the building as a direct measurement reference in the field. Measurement points are decided with consideration of the time constraint and size of the building. Each measurement point is within $2 \frac{1}{2}$ dry rooms $(6.25$ $\mathrm{m} \times 4 \mathrm{~m})$. A field survey was conducted twice at 14.00 WIB (UTC +7) on 2 November 2018 and 3 December 2018. The time at 14.00 WIB was selected because it was when the tobacco barn at an ideal position, where it had been through manual control processes such as opening the tabing and plastic covers.

- After that, the researchers measured the dimensions of the tobacco barn, ventilation, and the distance between tobacco barns with a measuring meter. Next, the researchers measured temperature, humidity, and wind speed in the building.

- Temperature is measured by holding the instrument at the height of approximately 80$100 \mathrm{~cm}$. The height is estimated by researchers as a safe distance below the wet tobacco hung above it, to avoid damaging the measurement instrument.

- After turning on the instrument and placing it at the specified height, the hygrometer thermometer will be allowed to stand for at least 1-2 minutes before reading and recording.

- At the same time, the researchers are doing wind measurements of the same height. The hot wire anemometer is oriented to the porous walls to face the prevailing wind.

- At last, the measurement results are written down at the measurement points on the floor plan.

- After researchers measured all 45 points inside the building, then measurements were conducted at 6 points outside the tobacco barn using the same steps.

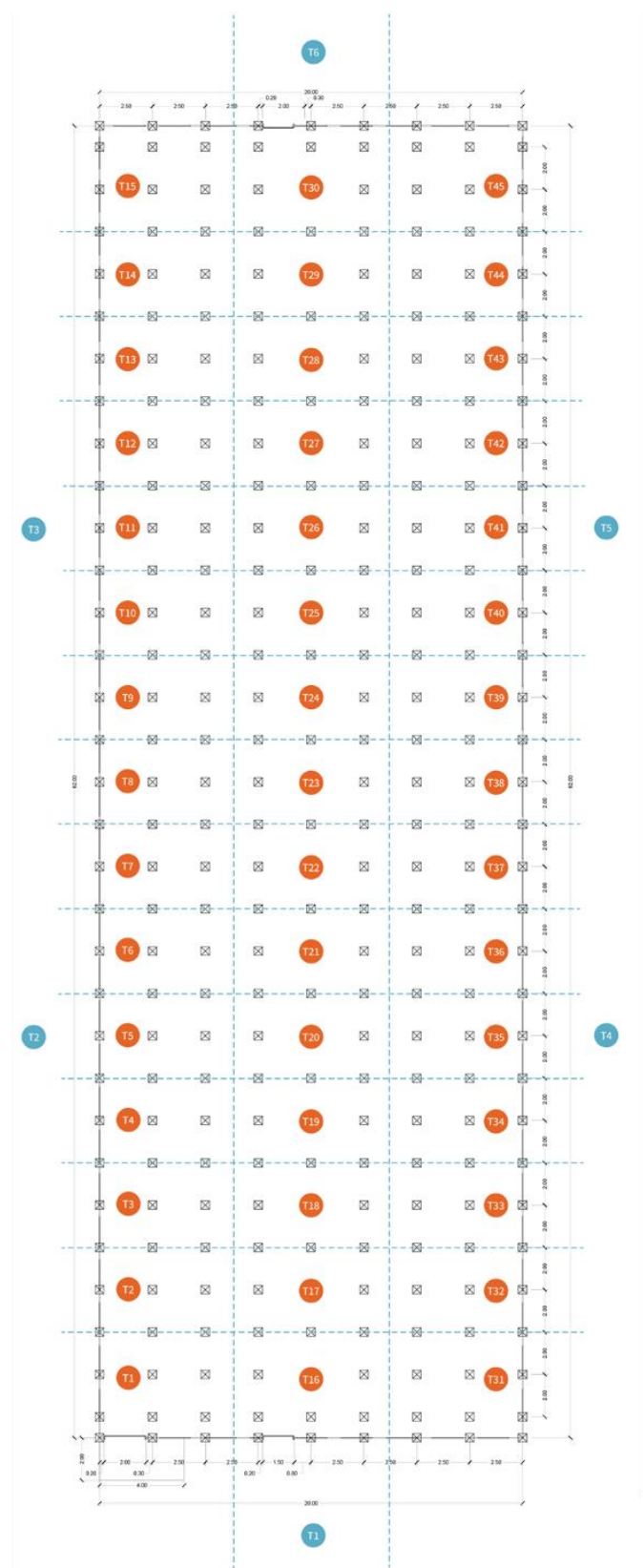

Figure 2 Measurement points inside (red dot) and outside (blue dot) of the building 
- $\quad$ After the field measurements, researchers conducted interviews with the tobacco barn workers to find out how to do manual control of the building during the air curing process.

- Research on the first and second day has the same steps.

- After the field survey is conducted, further data processing is carried out. The results of measurements of temperature, humidity, and wind speed in the building are then compared with the standard, whether it meets the ideal conditions during the air curing process.

- Furthermore, the measurement results of the tobacco barn dimensions are also compared with the rules of thumb for effective natural crossventilation $(\mathrm{W} \leq 5 \mathrm{H})$.

- After all the steps are carried out, the researchers analyze the overall concepts of Gudang Atag and the concept of air curing, then linking them with contemporary architecture to determine whether the concept can be adapted for contemporary buildings.

\section{FINDINGS}

\subsection{General Overview of Gudang Atag}

Gudang Atag in Jember has been used since 1856 and was first used by the Dutch as a tobacco dryer in the Sukowono area, northern Jember. The tobacco barn uses an air curing system as a way to dry the tobacco that has been arranged inside.

Gudang Atag in Jember Regency is used twice in a year, from July to mid-October to dry TBN tobacco and midOctober to December to dry Na-Oogst tobacco. The harvested tobacco will be sent to the barn to be dried with a hanging position in each galang (tobacco barn construction) starting from the very top, and each drying process takes about 20 days per harvest period.

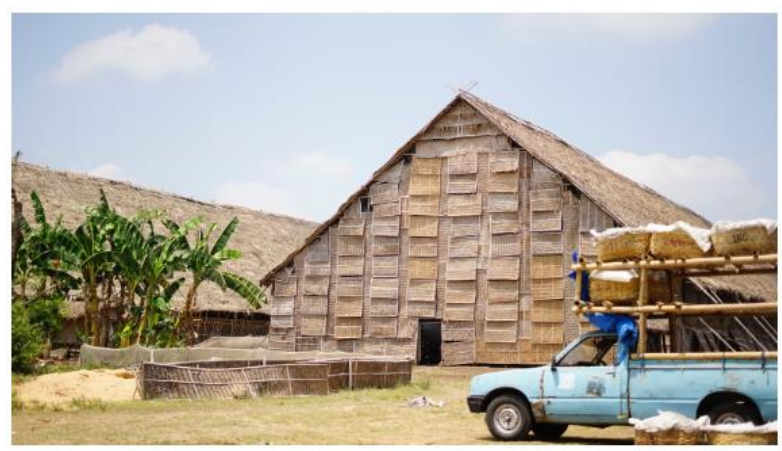

Figure 3 Gudang Atag Jember

\subsection{Climate Conditions in Jember Regency}

Jember Regency is located in the southern part of Java Island and is located at an altitude of $0-3,000 \mathrm{~m}$ above sea level. Jember Regency has a temperature ranging from 23 $31^{\circ} \mathrm{C}$ with an annual average of $26.6^{\circ} \mathrm{C}$. Rainfall ranges from $1,969 \mathrm{~mm}$ to $3,394 \mathrm{~mm}$ with an average of 2,396 $\mathrm{mm}$. The maximum wind speed in Jember Regency is estimated at around $11 \mathrm{Km} / \mathrm{h}$ and $14 \mathrm{Km} / \mathrm{h}$ [6].

\subsection{The Building Envelope of Gudang Atag}

The building envelope consists of woven bamboo, reeds, and plastic sheeting. The roof is made of a woven sugar cane leaves (blabad) that are tied with tutus/ gutos made of bamboo rope. Besides that, reed leaves can also be used. The roof has a varied thickness, ranging from $10 \mathrm{~cm}$ to 20 $\mathrm{cm}$. A bamboo reinforcement made is installed above the roof to prevent the roof from being exposed when there is a strong wind. The wall of the tobacco barn is made of woven bamboo (gedek) with a thickness of about $0.5 \mathrm{~cm}$ $2 \mathrm{~cm}$. The window/ ventilation, commonly called tabing, is also made of woven bamboo. The tabing is located on all sides of the tobacco barn to facilitate wind flow and crossventilation. The Gudang Atag structure is made of bamboo frames tied using BWG 16 wire, with additional nails applied on the tied parts that require stronger joints. The tobacco barn used simple materials that are easy to find in the surrounding environment, low-cost, low-maintenance, but durable for use in several harvest periods.

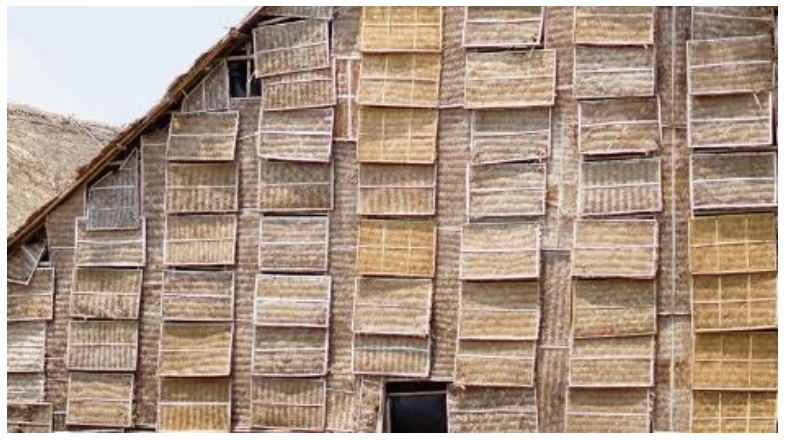

Figure 4 Wall material of Gudang Atag

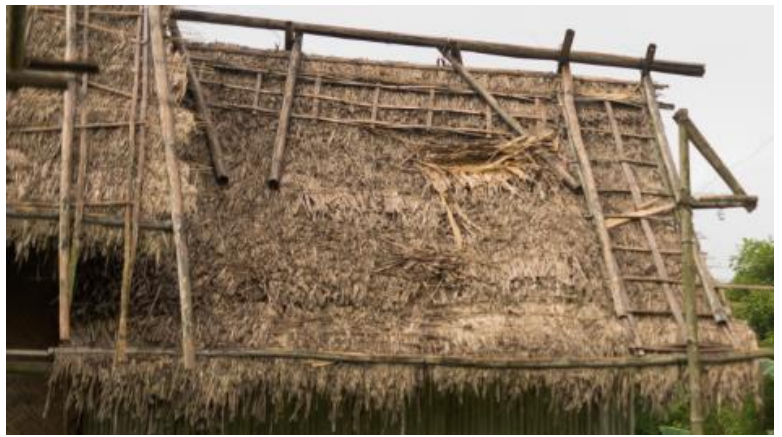

Figure 5 The tobacco barn roof with the reinforcement structure (cecek) 


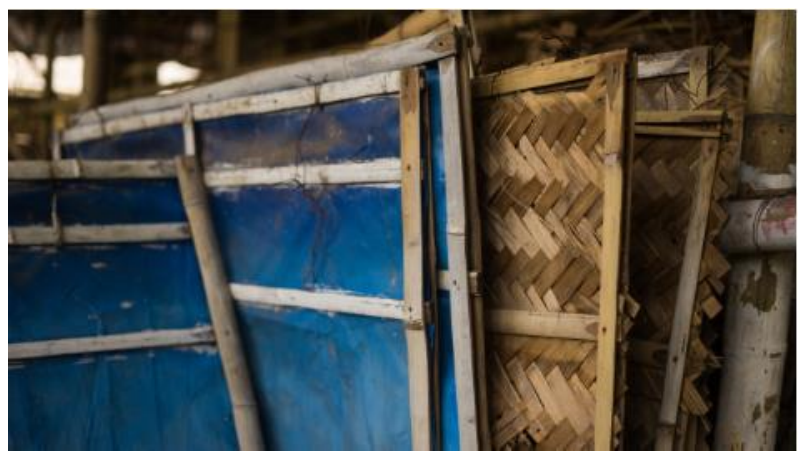

Figure 6 Ventilation (tabing) material of Gudang Atag

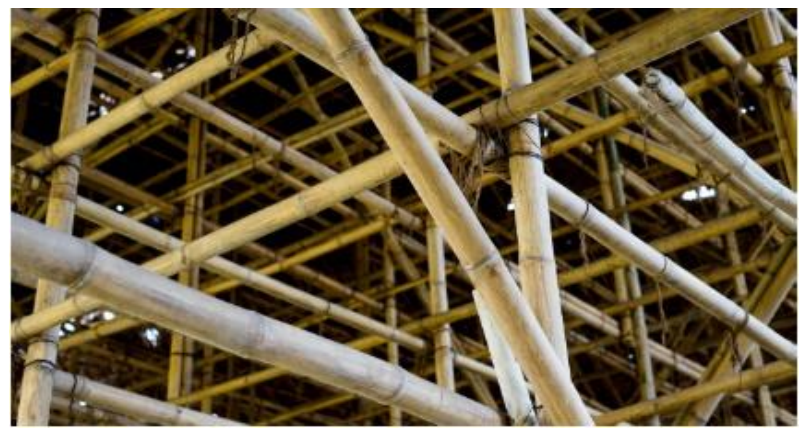

Figure 7 Bamboo structure of Gudang Atag

The envelope materials have an excellent ability to maintain thermal conditions in the building. Thatched roof and bamboo walls can keep the heat inside the room during the rainy season and retain heat from outside to enter the building in the dry season [7,8]. The soil has properties that can absorb cold so that the floor can also function as a cooling device in buildings [9]. The tarpaulin plastic sheeting can withstand heat and lock it inside a building.

\subsection{The Shape, Orientation, and Size of Gudang Atag}

Gudang Atag has a sloping roof and rectangular floor plan with a width of $20 \mathrm{~m}$, a length of $62 \mathrm{~m}$, and a height of $12.6 \mathrm{~m}$. Gudang Atag orientation under study extends north to south with the widest part facing west and east. The interior of the Gudang Atag is divided into 90 drying rooms with one wind chamber at the front and back of the building with a width of $1 \mathrm{~m}$ and a length of $20 \mathrm{~m}$, which is useful to facilitate the circulation of wind during the curing process.

The building orientation varies depending on the area used. In one site consisting of several Gudang Atag, there are two building orientations: two buildings stretching from east to west and four others from north to south. The orientation of the building is not influenced by the direction of the wind because all aspects of humidity and temperature are regulated manually by the building itself.
Each Gudang Atag with a building area of $1,240 \mathrm{~m} 2$ is built in a plot of land with an area of $2,000 \mathrm{~m} 2$. The distance between the buildings ranges from $3 \mathrm{~m}$ to $5 \mathrm{~m}$. Between the buildings, there are no tall trees that have the potential to shade the side of the building and inhibit wind circulation so that cross-ventilation continues to run well.
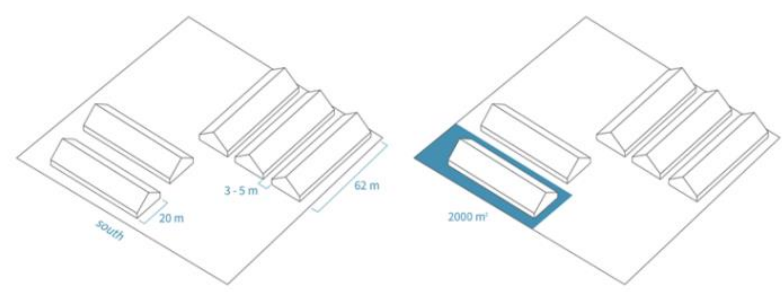

Figure 8 Size and orientation of Gudang Atag

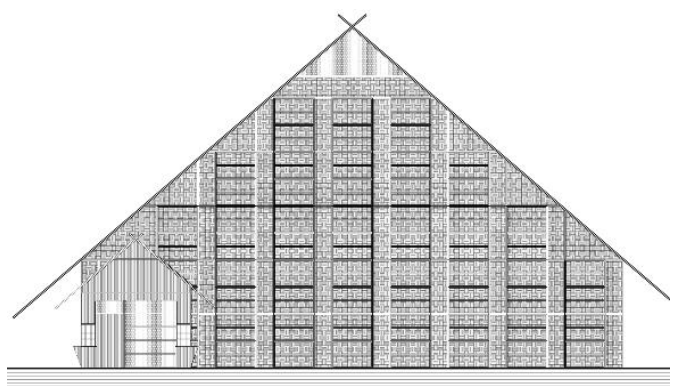

Figure 9 Gudang Atag front elevation

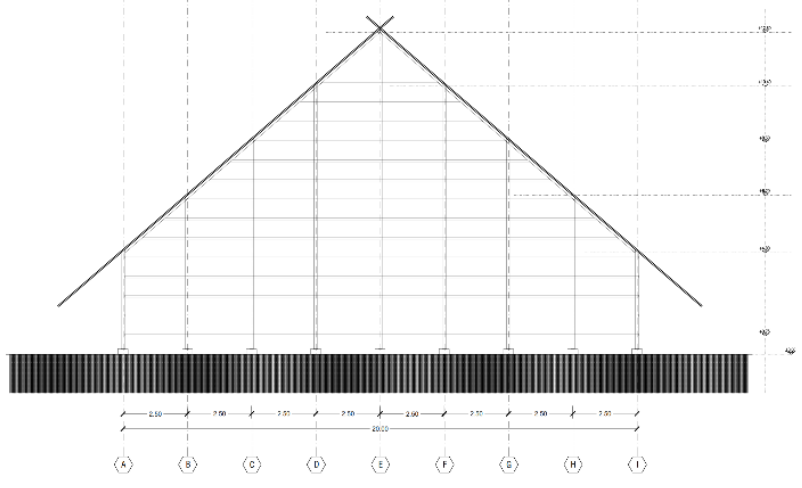

Figure 10 Gudang Atag section

\subsection{Measurement of Temperature, Humidity and Air Velocity}

Humidity, wind speed, and air temperature outside and inside Gudang Atag affect the air curing process. The ideal wind speed for the air curing process is around $1.5 \mathrm{~m} / \mathrm{s}$ [10]. High humidity can cause rotten tobacco, tobacco leaves that have dried become overgrown with fungus. Ideal humidity needed during the process of air curing ranges from $65-90 \%$. 


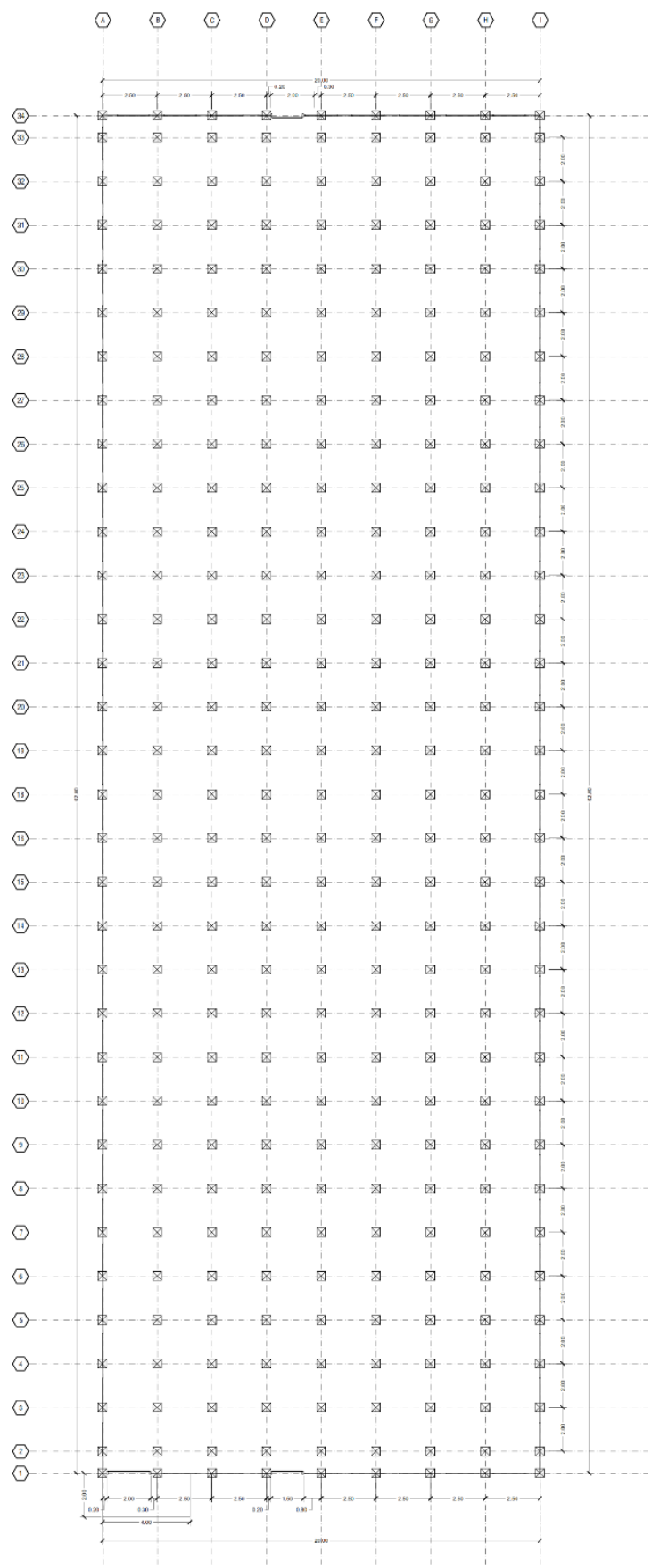

Figure 11 Floor plan of Gudang Atag

Cold air temperatures in Gudang Atag (below $20^{\circ} \mathrm{C}$ ) can inhibit the drying process of tobacco leaves. Air temperatures that are too low (below $23^{\circ} \mathrm{C}$ ) will obstruct the drying process (cessation of enzyme activity), which is marked by discoloration (yellowing). Warm enough temperatures $\left(25^{\circ} \mathrm{C}-30^{\circ} \mathrm{C}\right)$ will accelerate the process of drying the leaves naturally. Air temperatures that are too high in the tobacco barn (above $30^{\circ} \mathrm{C}$ ) will cause the green leaves to wilt and die, also cause the formation of high sugar resulting in a nemor color.
The first measurement was done on 2 November 2018 at 14.00 WIB (UTC+7) at 45 measuring points inside the building and 6 measuring points outside the building. The outdoor temperature, which is at $32.5^{\circ} \mathrm{C}$, drops to $28.5^{\circ} \mathrm{C}$ when measured inside the building. This temperature is the ideal temperature recommended in the tobacco curing process because it is within the range of $25^{\circ} \mathrm{C}-30^{\circ} \mathrm{C}$. Measured outdoor humidity is $62.5 \%$ and successfully raised to $81 \%$ inside the building. The moisture rate has successfully met the ideal indoor humidity range specified, namely in the range of $65 \%-90 \%$. The outdoor wind speed is measured at $1.6 \mathrm{~m} / \mathrm{s}$ and indoor at $0.2 \mathrm{~m} / \mathrm{s}$.

The second measurement was carried out on 3 December 2018 at 14.00 WIB $($ UTC+7) with the same measurement point. The calculated outdoor average temperature is $25.85^{\circ} \mathrm{C}$, rising to $28^{\circ} \mathrm{C}$ when measured inside the building. The temperature is already within the ideal temperature range recommended in the tobacco curing process. The measured output humidity was $86.5 \%$ and was successfully reduced to $82 \%$ inside the building. The moisture rate successfully fulfills the ideal indoor humidity range specified, which is in the range of $65 \%-90 \%$. Outdoor wind speed measured at $1.8 \mathrm{~m} / \mathrm{s}$ and indoor wind speed at $0.2 \mathrm{~m} / \mathrm{s}$.

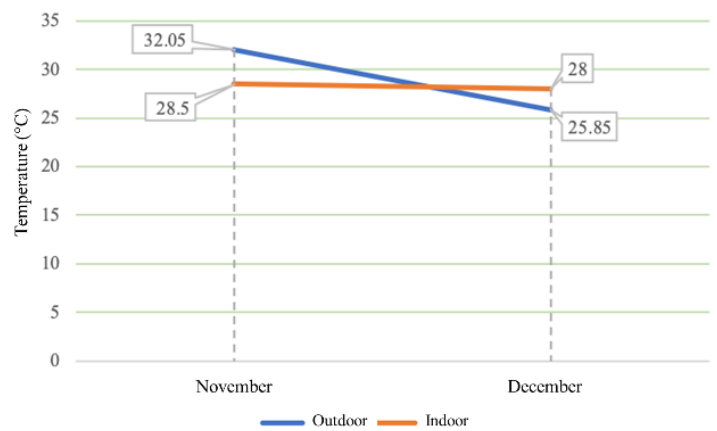

Figure 12 Comparison of temperature measurement

The high outdoor temperature at $32.05^{\circ} \mathrm{C}$ in November was successfully reduced to $28.5^{\circ} \mathrm{C}$ inside the building. The outdoor temperature in December, which was at $25.85^{\circ} \mathrm{C}$, turned out to be higher at $28^{\circ} \mathrm{C}$ inside the building. The two temperatures inside the building at two different months showed the similarity of indoor climate conditions with temperatures that are not much different.

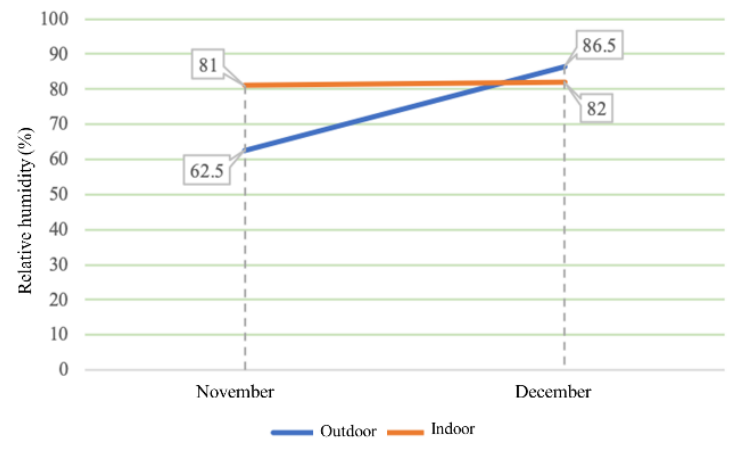

Figure 13 Comparison of Humidity Measurement 
Figure 13 shows outdoor humidity in November (62.5\%) is lower than in December $(86.5 \%)$, while the indoor humidity levels are not much different, $81 \%$ in November and $82 \%$ in December.

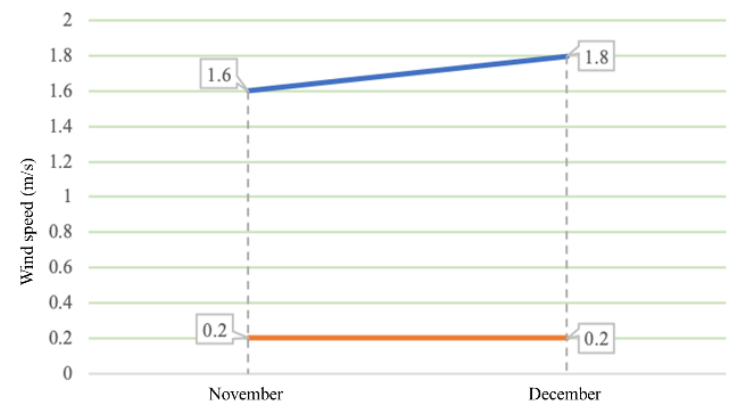

Outdoor _- Indoer

Figure 14 Comparison of Wind Speed Measurement

Figure 14 shows outdoor wind speeds in the two measurement months $(1.6 \mathrm{~m} / \mathrm{s}$ in November and $1.8 \mathrm{~m} / \mathrm{s}$ in December) are higher than the wind speed inside the building. Both indoor wind speeds show the same wind speed level of $0.2 \mathrm{~m} / \mathrm{s}$. From the three graphs above, it can be concluded that under two different conditions at two different months, indoor climate conditions inside the building can still meet ideal conditions: wind temperatures at $28^{\circ} \mathrm{C}$, the humidity of $81-82 \%$, and wind speeds of 0.2 $\mathrm{m} / \mathrm{s}$.

\subsection{Analysis of Air Curing Process}

Based on the two measurements above, it can be concluded that the air curing process that occurs inside Gudang Atag Warehouse is strongly influenced by the material of the building envelope. Also, manual control influences the desired climatic conditions inside the building. This finding is in line with Roesler's study [11] at a tobacco barn in Medan. Roesler said that the ventilation system in the tobacco barn consists of physical components in the form of buildings and practical components in the form of manual control from the barn workers.

The air curing can take place well if the building materials are appropriate, namely porous wall material with plastic sheeting as a second layer in the tobacco barn. The manual control process is carried out every day, with a total of 21 days, following climatic conditions and the age of the tobacco. The process requires humans (to open the tabing lid and plastic sheeting) and also the wind so that tobacco can dry at the desired time, coupled with the provision of fire during nighttime fumigation (so that tobacco does not mold). The amount of wind entering the tobacco barn is determined by the number of tabing opened and the large plastic sheeting. Depending on the time and weather, the treatment of the curing water process will be different.

Aside from material and manual control, one of the things that are very influential in this air curing process is crossventilation in the tobacco barn. An excellent tobacco barn requires much natural ventilation. Barn openings must be equivalent to $1 / 4$ or $1 / 3$ of the area of the wall and placed on the side facing the wind direction [12]. Duncan, G. et al. [13] also mentioned that the tobacco barn must be located in an open location with the longest side facing the direction of the prevailing wind to get maximum crossventilation.

A comparison of tobacco barn length, width, and height influences the performance of cross-ventilation inside the building. As a rule of thumb, the limiting depth for effective cross-ventilation is about five times the floor to ceiling height of a building [14]. Through a simple calculation of $\mathrm{W} \leq 5 \mathrm{H}$, it is found that the ratio of height and width of the barn both in the East-West and NorthSouth directions meets the rule of thumb for crossventilation calculation.

East-West direction:

$\mathrm{W}$ (barn length) $\quad=20 \mathrm{~m}$

$\mathrm{H}$ (barn height) $=12.6 \mathrm{~m}$

Cross-ventilation $=\mathrm{W} \leq 5 \mathrm{H}$

$20 \leq(12.6 \times 4)$

$20 \leq 63$

North-South direction:

$\mathrm{W}$ (barn length) $\quad=62 \mathrm{~m}$

$\mathrm{H}$ (barn height) $=12.6 \mathrm{~m}$

Cross-ventilation $=\mathrm{W} \leq 5 \mathrm{H}$

$62 \leq(5 \times 12.6)$

$62 \leq 63$

Based on the results of the study above, some important points that can be taken from the concept of air curing at Gudang Atag are:

- The porous material on the building envelope facilitates the wind to enter the building easily.

- Openings on all sides of the building significantly help distribute wind throughout the rooms inside the building. These openings are strongly influenced by manual controls carried out by the tobacco barn workers. Barn workers have an essential role in controlling the number of openings and how many tarpaulins in the warehouse are opened when tobacco is in the building, which is adjusted based on the age of the tobacco and environmental conditions outside the building to reach the ideal temperature of the tobacco drying process.

- The application of cross-ventilation with a size that meets the requirements $(\mathrm{W} \leq 5 \mathrm{H})$ makes the wind circulation inside the building more effective.

- The use of the wind chamber in the Gudang Atag as an empty area for wind circulation helps wind circulation in the warehouse. 
- Buildings with a high roof distance from the floor allow the temperature inside the building to remain cool and not stuffy because the hot winds in the building are not at human height, so workers inside the building do not feel the heat.

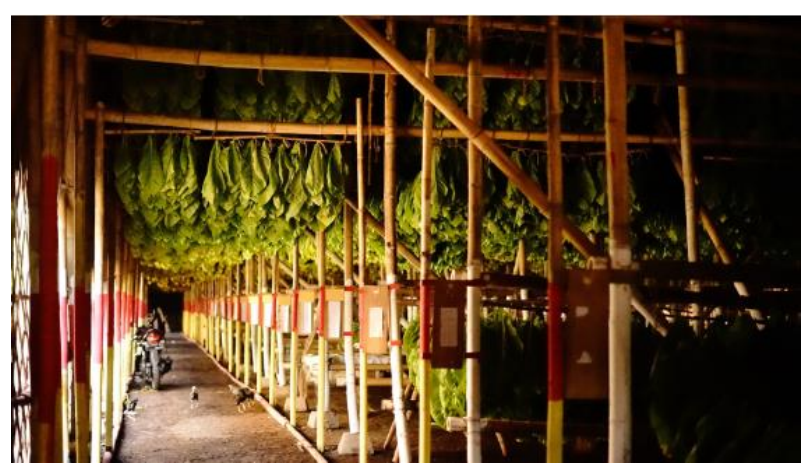

Figure 15 Tobacco curing process.

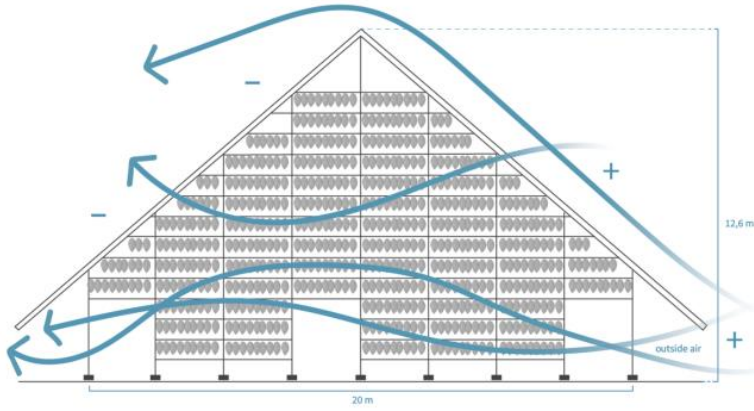

Figure 16 Cross-ventilation diagram

\subsection{Adaptation of Gudang Atag Design to Contemporary Architecture}

The success of Gudang Atag in maintaining comfort without mechanical support and its energy-independence can be used as an inspiration for passive building designs. The principles of Gudang Atag architecture that might be applicable in contemporary buildings are as follows:

Table 1 Adaptation of Gudang Atag design to contemporary architecture.

\begin{tabular}{|c|c|}
\hline $\begin{array}{c}\text { Principles of Gudang Atag } \\
\text { architecture }\end{array}$ & $\begin{array}{l}\text { The possible adaptation to } \\
\text { contemporary buildings }\end{array}$ \\
\hline $\begin{array}{l}\text { Bamboo structure with rope and nail } \\
\text { for connection }\end{array}$ & $\begin{array}{l}\text { Use a strong bamboo structure } \\
\text { Bamboo has almost the same strength as the tensile strength of steel within particular conditioning. } \\
\text { Besides, bamboo is flexible and environmentally friendly. This flexible nature makes bamboo can be used } \\
\text { as building structure materials, ranging from roof trusses, frame structure, walls, or building facades. }\end{array}$ \\
\hline $\begin{array}{l}\text { Slim rectangular building with width: } \\
\text { length: height ratio } \\
=5: 15,5: 3\end{array}$ & $\begin{array}{l}\text { Slim building form } \\
\text { The slim building form adapts to the humid tropical climate conditions in Indonesia by making the widest } \\
\text { side of the building facing north and south. Building geometry can be made simple, but the character and } \\
\text { image of the building must be strong. }\end{array}$ \\
\hline $\begin{array}{l}\text { Enclosed space with large ventilation } \\
\text { and porous facade }\end{array}$ & $\begin{array}{l}\text { Porous façade/ permeable enclosure } \\
\text { A porous façade allows the building to get sufficient light and wind. }\end{array}$ \\
\hline $\begin{array}{l}\text { Thermal comfort is achieved by } \\
\text { meeting cross-ventilation according to } \\
\text { the } \mathrm{W} \leq 5 \mathrm{H} \text { standard, the use of porous } \\
\text { materials, the presence of wind } \\
\text { chambers, and manual control of the } \\
\text { building. }\end{array}$ & $\begin{array}{l}\text { Comfort with passive cooling } \\
\text { The building is designed with a size that adjusts to the concept of cross-ventilation to get maximum } \\
\text { natural air. The use of sloping roofs can anticipate high rainfall in Indonesia. Manual control by building } \\
\text { users is also important to implement, alternatively, through an automation system in ventilation and } \\
\text { facades. Also, the wind chamber can be adapted into a terrace or corridor in a building to facilitate air } \\
\text { circulation. }\end{array}$ \\
\hline $\begin{array}{l}\text { The use of local and natural materials } \\
\text { in the form of bamboo and reeds }\end{array}$ & $\begin{array}{l}\text { Use of local materials } \\
\text { The use of local materials is very influential in environmental sustainability. Besides being easier to } \\
\text { obtain, cheaper, and environmentally friendly, it can also strengthen the character of the building's } \\
\text { locality. }\end{array}$ \\
\hline $\begin{array}{l}\text { Adequate clearance between tobacco } \\
\text { barns. }\end{array}$ & $\begin{array}{l}\text { Landscape exploration according to climate } \\
\text { The landscape in the area around the building is designed according to user requirements and following } \\
\text { the regulations. The arrangement of landscape elements is adjusted to the direction of the coming wind, } \\
\text { the sun path, and the open area according to local regulations. }\end{array}$ \\
\hline
\end{tabular}

\section{CONCLUSION}

Based on the results of measurements, interviews, and direct surveys, it can be concluded that Gudang Atag works by changing the non-ideal outdoor climate into an ideal indoor climate. The ideal indoor climate in the building is manifested by the use of porous building material coverings, the presence of cross-ventilation by the standards, and also the treatment in the form of manual control from the tobacco barn worker. The age of the tobacco inside the barn also influences the conditions inside. It is a controlling factor for making changes manually, such as ventilation (tabing) and plastic sheeting. Tobacco that tends to get wet makes some parts of the inside of the barn more humid than the side with drier tobacco.

From the explanation above, the main points of the air curing concept are: 
1. The use of porous material on the building envelope.

2. Openings on all sides of the building with manual control.

3. Application of cross-ventilation with a size that meets the requirements $(\mathrm{W} \leq 5 \mathrm{H})$.

4. The use of the wind chamber in Gudang Atag as an empty area for wind circulation helps optimize air circulation.

5. The high distance of the roof from the floor allows the temperature in the building to remain cold because the hot air is not equal to human height.

Some concepts from Gudang Atag might be adapted to contemporary architecture because contemporary architecture is one way to preserve the concept of traditional buildings with the present technology so that the values and principles of the building are not lost and forgotten. Some passive design strategies that can be applied as an adaptation of the concept of air curing at Gudang Atag are:

1. Use a strong bamboo structure

2. Slim building form

3. Porous façade/ permeable enclosure

4. Comfort with passive cooling

5. Use of local materials

Landscape exploration according to climate

\section{REFERENCES}

[1] World Meteorological Organization (WMO), WMO confirms past 4 years were warmest on record, 6 February 2019, https://public.wmo.int/en/media/pressrelease/wmo-confirms-past-4-years-were-warmestrecord

[2] World Meteorological Organization (WMO), The State of the Global Climate in 2018, 29 November 2018, http://ane4bf-datap1.s3-eu-west-

1.amazonaws.com/wmocms/s3fs-

public/ckeditor/files/Draft_Statement_7_February.pdf? 5.6rzIGwBm5lwDSTPbgprB2_EgrjzRVY

[3] Badan Meteorologi Klimatologi dan Geofisika (BMKG), 2019, Ekstrem Perubahan Iklim - Analisis Anomali Suhu Udara Rata-rata Bulan Juli 2019, https://www.bmkg.go.id/iklim/?p=ekstrem-perubahaniklim

[4] International Energy Agency (IEA), The Future of Cooling - Opportunities for energy-efficient air conditioning, 2018.

https://webstore.iea.org/download/direct/1036?fileNam e=The_Future_of_Cooling.pdf

[5] Padmo, Soegijanto, The cultivation of Vorstenlands tobacco in Surakarta Residency and Besuki tobacco in
Besuki Residency and its impact on the peasant economy and society: 1860-1960. Yogyakarta: Aditya Media, 1994, in Titien Saraswati, Vernakularitas Los, Bangunan Pengering Tembakau di Kabupaten Klaten, Jawa Tengah, DIMENSI TEKNIK ARSITEKTUR Vol. 36, No. 1 (2008) $65-74$

[6] Climate Jember, Climate Data, Oedheim: Climatedata.org, 2018. https://en.climate-

data.org/asia/indonesia/east-java/jember-50421/

Accessed on 22 January 2019.

[7] Suwantara K. \& Rini N, Kinerja Termal Rumah Tradisional Uma Kbubu. Widyariset, Vol. 15 No.3, (2012) 577-586.

[8] Nugroho, A.M, A Thermal Assessment of the Traditional House in Flores, Indonesia. J. Basic. Appl. Sci. Res., 2 (12) (2012) pp. 12795-12801.

[9] Lechner, Norbert, Heating, Cooling, Lighting, Jakarta: PT. Rajagrafindo Persada, 2007.

[10] Johnson, W. H., W. H. Henson, Jr., F. J. Hassler, and R. W. Watkins: Bulk curing of bright leaf tobacco; Tobacco Science IV, pp. 49-55, 1960.

[11] Roesler, S, Natural Ventilation, Revisited: Pioneering a New Climatisation, Culture, Singapore: Future Cities Laboratory, 2015.

[12] Duncan. G. and Swetnam L.D, Selecting an AirCure Tobacco Housing and Curing Facility, Kentucky: The University of Kentucky, College of Agriculture, 2005.

[13] Duncan, G, Kentucky Tobacco Production Guide, Kentucky: The University of Kentucky, College of Agriculture, 2008.

[14] Yang T., Clements-Croome D.J, Natural Ventilation in Built Environment. In: Meyers R. (eds) Encyclopedia of Sustainability Science and Technology, Springer, New York, NY, 2018. 